\title{
Factors associated with length of stay in a neonatal intensive care unit in Iran
}

\author{
Fatemeh Kheiry ${ }^{1}$, Abolfazl Mohammadbeigi ${ }^{2}$, ${ }^{*}$ Sima Afrashteh ${ }^{3}$, Sadegh Kargarian-Marvasti ${ }^{4}$, Salma \\ Naderi $^{5}$, Hosein Saadat ${ }^{6}$, Leila Nami Nazari ${ }^{7}$
}

Sri Lanka Journal of Child Health, 2019; 48(3): 226-232

\begin{abstract}
Background: The length of stay (LOS) is a useful indicator of health and prediction of the LOS in the neonatal intensive care unit (NICU) has drawn increasing attention over the past years.
\end{abstract}

Objectives: To determine factors associated with infant's LOS in the NICU in Bandar Abbas city, Southern Iran, between 2016 and 2017.

Method: This cohort study reviewed 603 medical records of all NICU admitted newborns. Data were collected using data collection forms. The Cox multiple hazards regression model determined the factors associated with the infant's LOS. Data was analysed using SPSS, version 21. The significance level was set at 0.05 .

Results: The median LOS in NICU was 9 days. The results of multiple Cox proportional hazards regression model showed that type of feeding, umbilical and central venous catheterization, mechanical ventilation, nosocomial infection, acute renal failure, blood transfusion, and antibiotic therapy were significantly associated with LOS in the NICU $(p<0.05)$.

\begin{abstract}
${ }^{1}$ Msc of Nursing, Pediatrics Hospital, Hormozgan University of Medical Sciences, Bandar Abbas, Iran, ${ }^{2}$ Research Centre Environmental pollutants, Qom University of Medical Sciences, Qom, Iran, ${ }^{3}$ Msc of Epidemiology, Bushehr University of Medical Sciences,, Bushehr, Iran, ${ }^{4}$ Msc of Epidemiology, Isfahan University of Medical Sciences, Isfahan, Iran, ${ }^{5}$ Associate Professor, Department of Pediatrics, Faculty of Medicine, Clinical Research Development Centre of Children Hospital, Hormozgan University of Medical Sciences, Bandar Abbas, Iran, ${ }^{6}$ Assistant Professor, Department of Pediatrics, Faculty of Medicine, Clinical Research Development Centre of Children Hospital, Hormozgan University of Medical Sciences,, Bandar Abbas, Iran, ${ }^{7}$ Vice-Chancellor for Public Health, Bushehr University of Medical Sciences, Bushehr, Iran

*Correspondence: sima.afrashte3@gmail.com
\end{abstract}

iD.

orcid.org/ 0000-0002-4276-2084

(Received on 28 September 2018: Accepted after revision on 16 November 2018)

The authors declare that there are no conflicts of interest

Personal funding used for the project.

Open Access Article published under the Creative

Commons Attribution CC-BY (CC) (P)
Conclusions: The type of feeding, umbilical and central venous catheterization, mechanical ventilation, nosocomial infection, acute renal failure, blood transfusion, and antibiotic therapy were significantly associated with LOS in the NICU.

DOI: http://dx.doi.org/10.4038/sljch.v48i3.8757

(Keywords: Hospital, neonatal, Cox multiple hazards regression, survival)

\section{Introduction}

Around $38 \%$ of all deaths occur in children below 5 years of age in the neonatal period, approximately $75 \%$ of them occurring in the first week of birth ${ }^{1,2}$. In the United States, infant mortality rate was 6.7 deaths per 1000 live births in $2011^{3}$. Prediction of the length of stay (LOS) in the neonatal intensive care unit (NICU) is a major determinant of the cause of infant deaths ${ }^{4,5}$. Such a prediction of LOS facilitates physician-parent communication regarding NICU LOS for infants ${ }^{6}$. Estimation of LOS may reduce parental anxiety during an infant's hospitalization ${ }^{7}$. Further, knowledge about factors associated with LOS may help design strategic plans to reduce hospitalization costs, improve emotional affinity between parents and infants, increase the quality of healthcare services, and thus increase economic benefits for the society ${ }^{8}$. Reduced NICU LOS for newborns leads to reduced burden of medical costs on government and families, and increased hospital capacity to admit new patients 9 .

\section{Objective}

To determine factors associated with the infant's LOS in the NICU in Bandar Abbas city, Southern Iran, between 2016 and 2017.

\section{Method}

This retrospective cohort study reviewed 603 medical records of all NICU admitted newborns. First, 600 infants admitted to the NICU of the Paediatric Department of Bandar Abbas hospital with LOS longer than 24 hours were selected as the target population. Data were gathered using data collection forms on age, gender, type of feeding, gestational age, type of delivery, presence of various infections in infant, umbilical and central venous catheterization, antibiotic therapy, mechanical ventilation, photomicrography, phototherapy, blood transfusion, type of admission, and patient's condition at the time of discharge. The NICU LOS was considered as a survival variable and the desired 
outcome was discharge from hospital with physician approval. Infants who died, or who were discharged from hospital against medical advice were considered as censored data. As in other analyses, in survival analysis, multiple regression model can control for confounding variables and form an equation of the factors associated with survival. Variables significantly associated with NICU LOS were selected using Cox multiple hazards regression, and then entered into multiple regression analysis. After evaluation of fitted model, significant variables were analysed through multivariate Cox hazards regression with backward LR. Data was analysed using SPSS, version 21. For best model fitting, the significance level to include and exclude variables were set at 0.02 , and 0.05 , respectively. The study was approved by the Ethics Committee of the Hormozgan University of Medical Sciences (Ref. no: IR.HUMS.REC.1397.072).

\section{Results}

In this study, of 603 patients, 493 (81.8\%) were fully treated at the time of discharge, and $110(18.2 \%)$ died or left against medical advice. Demographic characteristics and extracted data on study variables from medical reports are shown in Table 1.

Table1: Demographics and records of patients included in this study ( $n=603)$

\begin{tabular}{|c|c|c|c|c|}
\hline \multicolumn{2}{|l|}{ Variable } & Median (IQR) & Frequency (\%) & LOS (IQR) \\
\hline Age (days) & & $02(06)$ & & \\
\hline Weight $(g)$ & & $2600(1350)$ & & \\
\hline $\begin{array}{l}\text { Gender } \\
\text { Male } \\
\text { Female }\end{array}$ & & & $\begin{array}{l}360(59.7) \\
243(40.3)\end{array}$ & $\begin{array}{l}09(12) \\
11(13)\end{array}$ \\
\hline $\begin{array}{l}\text { Type of delivery } \\
\text { Vaginal } \\
\text { Caesarean Section }\end{array}$ & & & $\begin{array}{l}298(49.4) \\
305(50.6)\end{array}$ & $\begin{array}{l}09(13) \\
10(12)\end{array}$ \\
\hline $\begin{array}{l}\text { Type of feeding } \\
\text { Breast feeding } \\
\text { Formula } \\
\end{array}$ & & & $\begin{array}{l}340(56.4) \\
263(43.6)\end{array}$ & $\begin{array}{l}07(12) \\
11(12) \\
\end{array}$ \\
\hline Cause of hospitalisation & & & & \\
\hline Hospital Infection & $\begin{array}{l}\text { Yes } \\
\text { No }\end{array}$ & & $\begin{array}{l}327(54.2) \\
276(45.8)\end{array}$ & $\begin{array}{l}12(18) \\
08(08)\end{array}$ \\
\hline Gastrointestinal disorders & $\begin{array}{l}\text { Yes } \\
\text { No }\end{array}$ & & $\begin{array}{l}132(21.9) \\
471(78.1)\end{array}$ & $\begin{array}{l}09(16) \\
10(11)\end{array}$ \\
\hline Respiratory disorders* & $\begin{array}{l}\text { Yes } \\
\text { No }\end{array}$ & & $\begin{array}{l}440(73.0) \\
163(27.0)\end{array}$ & $\begin{array}{l}10(13) \\
08(09)\end{array}$ \\
\hline Heart disorders & $\begin{array}{c}\text { Yes } \\
\text { No }\end{array}$ & & $\begin{array}{l}129(21.4) \\
447(78.6)\end{array}$ & $\begin{array}{c}09(15) \\
09(11.25)\end{array}$ \\
\hline Genetic disorders** & $\begin{array}{l}\text { Yes } \\
\text { No }\end{array}$ & & $\begin{array}{c}61(10.1) \\
542(89.9)\end{array}$ & $\begin{array}{l}11(18) \\
09(12)\end{array}$ \\
\hline Metabolic disorders & $\begin{array}{l}\text { Yes } \\
\text { No }\end{array}$ & & $\begin{array}{c}51(08.5) \\
551(91.5)\end{array}$ & $\begin{array}{l}12(25) \\
09(12)\end{array}$ \\
\hline Acute renal failure & $\begin{array}{l}\text { Yes } \\
\text { No }\end{array}$ & & $\begin{array}{c}42(07.0) \\
561(93.0)\end{array}$ & $\begin{array}{c}11.5(22.5) \\
09(11)\end{array}$ \\
\hline Pneumothorax $* * *$ & $\begin{array}{l}\text { Yes } \\
\text { No }\end{array}$ & & $\begin{array}{c}53(08.8) \\
550(91.2)\end{array}$ & $\begin{array}{l}10(16) \\
09(12)\end{array}$ \\
\hline Intraventricular haemorrhage & $\begin{array}{l}\text { Yes } \\
\text { No }\end{array}$ & & $\begin{array}{c}76(12.6) \\
527(87.4)\end{array}$ & $\begin{array}{c}12.5(13.7) \\
09(12)\end{array}$ \\
\hline Antibiotic therapy & $\begin{array}{l}\text { Yes } \\
\text { No }\end{array}$ & & $\begin{array}{l}588(97.5) \\
15(02.5)\end{array}$ & $\begin{array}{l}9.5(12) \\
05(09)\end{array}$ \\
\hline Umbilical venous catheterization & $\begin{array}{l}\text { Yes } \\
\text { No }\end{array}$ & & $\begin{array}{c}54(09.0) \\
549(91.0)\end{array}$ & $\begin{array}{l}05(14.25) \\
10(12)\end{array}$ \\
\hline Umbilical arterial catheterisation & $\begin{array}{c}\text { Yes } \\
\text { No }\end{array}$ & & $\begin{array}{c}06(01.0) \\
597(99.0)\end{array}$ & $\begin{array}{l}05(14) \\
10(12)\end{array}$ \\
\hline Central venous catheterization & $\begin{array}{l}\text { Yes } \\
\text { No }\end{array}$ & & $\begin{array}{c}38(06.3) \\
565(93.7)\end{array}$ & $\begin{array}{l}03.5(33.75) \\
10(12)\end{array}$ \\
\hline Mechanical ventilation & $\begin{array}{l}\text { Yes } \\
\text { No }\end{array}$ & & $\begin{array}{l}163(27.0) \\
440(73.0)\end{array}$ & $\begin{array}{l}10(12) \\
05(11)\end{array}$ \\
\hline Oxygen Therapy & $\begin{array}{l}\text { Yes } \\
\text { No }\end{array}$ & & $\begin{array}{l}523(86.7) \\
80(13.3)\end{array}$ & $\begin{array}{l}10(12) \\
07(08)\end{array}$ \\
\hline Surgery during hospitalization & $\begin{array}{l}\text { Yes } \\
\text { No }\end{array}$ & & $\begin{array}{c}83(13.8) \\
520(86.2)\end{array}$ & $\begin{array}{l}10(12) \\
09(13)\end{array}$ \\
\hline Blood transfusion & $\begin{array}{l}\text { Yes } \\
\text { No }\end{array}$ & & $\begin{array}{l}269(44.6) \\
334(55.4)\end{array}$ & $\begin{array}{l}14(20) \\
07(08)\end{array}$ \\
\hline Phototherapy & $\begin{array}{l}\text { Yes } \\
\text { No }\end{array}$ & & $\begin{array}{l}257(42.6) \\
346(57.4)\end{array}$ & $\begin{array}{l}10(13) \\
09(13)\end{array}$ \\
\hline Photomicrography & $\begin{array}{l}\text { Yes } \\
\text { No }\end{array}$ & & $\begin{array}{l}526(87.2) \\
77(12.8)\end{array}$ & $\begin{array}{l}10(13) \\
08(07)\end{array}$ \\
\hline $\begin{array}{l}\text { Type of admission } \\
\text { Emergency admission } \\
\text { Admission from other units } \\
\text { Referral from other hospitals }\end{array}$ & & & $\begin{array}{c}163(27.0) \\
87(14.4) \\
353(58.5) \\
\end{array}$ & $\begin{array}{l}09(12) \\
11(09) \\
09(14)\end{array}$ \\
\hline
\end{tabular}

*excluding pneumothorax, **congenital deaf-blindness \& cardiac abnormalities and Down syndrome (trisomy 21) ***excluding respiratory disorders 
The median LOS in NICU was 9 days with a hospital interquartile range (IQR) of 12 days. The median and IQR of LOS were 9 and 12 days for male infants, and 11 and 13 days for female infants. Also, the median and IQR of LOS were 10 and 11 days for fully treated infants at discharge, and 4.5 and 9.25 for infants who were dead or discharged with parental consent but without treatment.

Univariate analysis revealed that gender, type of feeding, gastrointestinal disorder, heart disorders, umbilical and central venous catheterization, pneumothorax, intraventricular hemorrhage, mechanical ventilation, nosocomial infection, acute renal failure, blood transfusion, phototherapy, and antibiotic therapy were significantly associated with LOS in NICU $(p<0.05)$. However, multivariate Cox regression model indicated that the type of feeding (HR: 3.6, $p<0.001$ ), umbilical (HR: 1.67, $\mathrm{p}=0.023$ ) and central (HR: 2.33, $\mathrm{p}=0.005)$ venous catheterization, mechanical ventilation (HR:4.12, $\mathrm{p}<0.001$ ), nosocomial infection (HR:1.6, $\mathrm{p}=0.04$ ), acute renal failure (HR: 2.06, p $=0.003$ ), blood transfusion (HR:1.86, $\mathrm{p}=0.021)$, phototherapy (HR:2.02, $\mathrm{p}=0.001)$ and antibiotic therapy (HR:2.64, $\mathrm{p}=0.027$ ) were significantly associated with LOS in NICU $(p<0.05)$. (Table 2)

Table 2: Univariate analysis and multivariate regression model of Cox

\begin{tabular}{|c|c|c|c|c|c|c|}
\hline \multirow[t]{2}{*}{ Variable } & \multicolumn{3}{|c|}{ Univariate analysis } & \multicolumn{3}{|c|}{ Multivariate analysis } \\
\hline & Hazard ratio & $95 \%$ CI & $p$ value & Hazard ratio & $95 \% \mathrm{CI}$ & $p$ value \\
\hline $\begin{array}{l}\text { Gender } \\
\text { Male } \\
\text { Female }\end{array}$ & $\begin{array}{c}1 \\
0.54\end{array}$ & $0.36-0.82$ & $\overline{0.004}$ & $\begin{array}{c}1 \\
0.72\end{array}$ & $\stackrel{-}{-}$ & - \\
\hline $\begin{array}{l}\text { Type of delivery } \\
\text { Vaginal } \\
\text { Caesarean Section }\end{array}$ & $\begin{array}{c}1 \\
1.03\end{array}$ & $0.71-1.51$ & 0.84 & $\mathrm{NI}^{*}$ & - & - \\
\hline $\begin{array}{l}\text { Type offeeding } \\
\text { Breastfeeding } \\
\text { Formula }\end{array}$ & $\begin{array}{c}1 \\
2.41\end{array}$ & $1.11-3.82$ & $<\overline{0.001}$ & $\begin{array}{c}1 \\
3.6\end{array}$ & $2.02-4.83$ & $<\overline{-} \cdot \overline{001}$ \\
\hline $\begin{array}{lr}\text { Hospital Infection: } & \text { No } \\
& \text { Yes }\end{array}$ & $\begin{array}{c}1 \\
2.10\end{array}$ & $\begin{array}{c}- \\
1.31-3.25\end{array}$ & $\begin{array}{c}- \\
0.001\end{array}$ & $\begin{array}{c}1 \\
1.6\end{array}$ & $\begin{array}{c}- \\
1.40-2.07\end{array}$ & $\begin{array}{c}- \\
0.04\end{array}$ \\
\hline Gastrointestinal disorders: & $\begin{array}{c}1 \\
1.53\end{array}$ & $\begin{array}{c}- \\
1.02-2.29\end{array}$ & $\overline{0.03}$ & $\begin{array}{c}1 \\
0.85\end{array}$ & $\begin{array}{c}- \\
0.54-1.34\end{array}$ & - \\
\hline Respiratory disorders: & $\begin{array}{c}1 \\
1.52\end{array}$ & $\begin{array}{c}- \\
0.91-2.53\end{array}$ & $\begin{array}{c}- \\
0.1\end{array}$ & $\begin{array}{c}\mathrm{NI}^{*} \\
-\end{array}$ & $\begin{array}{l}- \\
-\end{array}$ & $\begin{array}{l}- \\
=\end{array}$ \\
\hline Heart disorders: & $\begin{array}{c}1 \\
2.31 \\
\end{array}$ & $1.56-3.42$ & $\begin{array}{c}- \\
<0.001\end{array}$ & $\begin{array}{c}1 \\
1.10 \\
\end{array}$ & $0.71-1.77$ & $\overline{-}-$ \\
\hline Genetic disorders: & $\begin{array}{c}1 \\
1.80 \\
\end{array}$ & $\begin{array}{c}- \\
1.10-2.93 \\
\end{array}$ & 0.01 & $\begin{array}{c}1 \\
1.41 \\
\end{array}$ & $\begin{array}{c}- \\
0.82-2.41\end{array}$ & $\overline{-}$ \\
\hline Metabolic disorders: & $\begin{array}{c}1 \\
1.29\end{array}$ & $0.74-2.24$ & $-\overline{35}$ & $\mathrm{NI}^{*}$ & $\begin{array}{l}- \\
-\end{array}$ & $\begin{array}{l}- \\
=\end{array}$ \\
\hline Acute renal failure: & $\begin{array}{c}1 \\
5.14\end{array}$ & $\begin{array}{c}- \\
2.08-0.48\end{array}$ & $\begin{array}{c}- \\
<0.001\end{array}$ & $\begin{array}{c}1 \\
2.06\end{array}$ & $\begin{array}{c}- \\
1.20-3.31\end{array}$ & $\overline{-}-\overline{0}$ \\
\hline Pneumothorax: & $\begin{array}{c}1 \\
2.28\end{array}$ & $3.56-7.84$ & $<\overline{-}$ & $\begin{array}{c}1 \\
1.22\end{array}$ & $\begin{array}{c}- \\
0.78-1.91\end{array}$ & $-\overline{37}$ \\
\hline Intraventricular hemorrhage: & $\begin{array}{c}1 \\
1.71\end{array}$ & $\begin{array}{c}- \\
1.01-2.67\end{array}$ & $\begin{array}{c}- \\
0.01\end{array}$ & $\begin{array}{c}1 \\
1.46\end{array}$ & $\begin{array}{c}- \\
0.88-1.44\end{array}$ & $\begin{array}{c}- \\
0.14\end{array}$ \\
\hline Antibiotic therapy: & $\begin{array}{c}1 \\
3.31 \\
\end{array}$ & $\begin{array}{c}- \\
1.44-7.60 \\
\end{array}$ & $\overline{0.005}$ & $\begin{array}{c}1 \\
2.64 \\
\end{array}$ & $1.11-6.24$ & $\overline{-}$ \\
\hline $\begin{aligned} & \text { Umbilical venous catheterization: } \text { No } \\
& \text { Yes }\end{aligned}$ & $\begin{array}{c}1 \\
5.32 \\
\end{array}$ & $\begin{array}{c}- \\
3.54-7.90 \\
\end{array}$ & $<\overline{0.001}$ & $\begin{array}{c}1 \\
1.67 \\
\end{array}$ & $\begin{array}{c}- \\
1.07-2.64 \\
\end{array}$ & $\overline{0}-\overline{023}$ \\
\hline $\begin{array}{r}\text { Umbilical arterial catheterization: } \text { No }^{\text {Yes }} \\
\text { Yes }\end{array}$ & $\begin{array}{c}1 \\
4.17\end{array}$ & $\begin{array}{c}- \\
0.56-5.8\end{array}$ & $-\overline{1}$ & $\begin{array}{c}\mathrm{NI}^{*} \\
-\end{array}$ & $\begin{array}{l}- \\
-\end{array}$ & $\begin{array}{l}- \\
=\end{array}$ \\
\hline $\begin{array}{ll}\text { Central venous catheterization: } & \text { No } \\
& \text { Yes }\end{array}$ & $\begin{array}{c}1 \\
2.12\end{array}$ & $\begin{array}{c}- \\
-21-3.71\end{array}$ & $\overline{0.009}$ & $\begin{array}{c}1 \\
2.33 \\
\end{array}$ & $\begin{array}{c}- \\
1.21-4.25\end{array}$ & $\overline{0.005}$ \\
\hline Mechanical ventilation: & $\begin{array}{c}1 \\
2.25\end{array}$ & $\begin{array}{c}- \\
1.2-4.63\end{array}$ & $\begin{array}{c}- \\
<0.001\end{array}$ & $\begin{array}{c}1 \\
4.12\end{array}$ & $\begin{array}{c}- \\
1.21-5.17\end{array}$ & $\begin{array}{c}- \\
<0.001\end{array}$ \\
\hline Oxygen therapy: & $\begin{array}{c}1 \\
0.77\end{array}$ & $0.44-1.33$ & 0.35 & $\mathrm{NI}^{*}$ & $\begin{array}{l}- \\
-\end{array}$ & $\begin{array}{l}- \\
=\end{array}$ \\
\hline $\begin{array}{ll}\text { Surgery during hospitalization: } & \text { No } \\
& \text { Yes }\end{array}$ & $\begin{array}{c}1 \\
0.82 \\
\end{array}$ & $\begin{array}{c}- \\
0.47-1.43\end{array}$ & $\begin{array}{c}- \\
0.49\end{array}$ & $\begin{array}{c}\mathrm{NI}^{*} \\
-\end{array}$ & $\begin{array}{l}- \\
-\end{array}$ & $\begin{array}{l}- \\
=\end{array}$ \\
\hline Blood transfusion: & $\begin{array}{c}1 \\
3.64 \\
\end{array}$ & $2.24-5.90$ & $<\overline{-}$ & $\begin{array}{c}1 \\
1.86 \\
\end{array}$ & $\overline{-}-\overline{1.09-3.15}$ & $\overline{0.021}$ \\
\hline Phototherapy: & 0.56 & $0.38-0.82$ & 0.003 & 2.02 & $1.35-3.03$ & 0.001 \\
\hline Photomicrography: & $\begin{array}{c}1 \\
4.34\end{array}$ & $\begin{array}{c}- \\
1.37-13.7\end{array}$ & $\begin{array}{c}- \\
0.01\end{array}$ & $\begin{array}{c}1 \\
1.41\end{array}$ & $0.43-4.59$ & $\overline{-}$ \\
\hline $\begin{array}{l}\text { Type of admission } \\
\text { Emergency admissions } \\
\text { Admission from other units } \\
\text { Referral from other hospitals }\end{array}$ & $\begin{array}{c}1 \\
0.19 \\
1.34\end{array}$ & $\begin{array}{c}- \\
0.04-0.82 \\
0.82-2.19\end{array}$ & $\begin{array}{l}- \\
0.22 \\
0.23\end{array}$ & $\begin{array}{c}\mathrm{NI}^{*} \\
- \\
-\end{array}$ & $\begin{array}{l}- \\
-\end{array}$ & $\begin{array}{l}- \\
-\end{array}$ \\
\hline
\end{tabular}




\section{Discussion}

Results from the Cox regression model suggest that type of feeding, umbilical and central venous catheterization, mechanical ventilation, nosocomial infection, acute renal failure, blood transfusion, and antibiotic therapy were significantly associated with LOS in NICU. The median LOS in NICU was 9 days ( 9 in males vs. 11 in females). A similar study conducted in Iran reported the median NICU LSO as 9 days, which is in accordance with the present study $^{8}$. Results show that the majority of the NICU admitted infants are male. A study showed that male infants are more likely to be admitted in $\mathrm{NICU}^{8,10}$. However, the LOS was higher among female infants than in male infants, which is supported by previous studies $^{8}$. It appears that male infants are more susceptible during the first days of birth compared with female infants.

In addition, infants with exclusive breastfeeding displayed lower LOS in NICU, whereas formula fed infants displayed prolonged LOS in NICU. A number of studies showed the protective effect of exclusive breastfeeding on respiratory infectious diseases including allergies, asthma, pneumonia and bronchiolitis ${ }^{11,12}$, and gastrointestinal infections with acute diarrhoea ${ }^{12,13}$. Besides, a study revealed that exclusive breastfeeding significantly reduced the risk of necrotizing enterocolitis among premature infants in NICU ${ }^{14,15}$. Thus, infants deprived from breastfeeding are more likely to develop various infections.

Infants admitted to NICU with nosocomial infection normally have higher LOS. Kandi Kele and colleagues stated that infections increased NICU LOS among infants ${ }^{8}$. Another study in Rasht city showed that $16.3 \%$ of NICU admitted infants reported nosocomial infection ${ }^{16}$. Joseph and colleagues also reported a higher prevalence of nosocomial infection in low birth weight and NICU admitted infants ${ }^{17}$. Infants who received antibiotic therapy during their stay in NICU, reported higher NICU LSO. As such, patients with nosocomial infection require antibiotic therapy, which considerably increases LOS in NICU ${ }^{18}$. Further, umbilical and central venous catheterisation and mechanical ventilation have been shown to increase NICU LOS. A study conducted in Iran showed that infants with respiratory disorders require mechanical ventilation during stay in NICU, as use of mechanical ventilation devices increases LOS in NICU, which is compatible with the findings of our study ${ }^{19}$.The results of several studies showed higher mortality rates among infants who used mechanical ventilation ${ }^{20,21}$.

According to the literature, infants with severe conditions and respiratory disorders need special medical care and services such as mechanical ventilation and NICU admission to prevent death due to these complications. Kandi Kele and colleagues also revealed that central venous catheterization increased LOS in $\mathrm{NICU}^{8}$. The findings of previous studies have shown that renal failure is associated with outcomes ${ }^{22}$ and infant mortality $^{23,24}$. In addition, factors such as sepsis, congenital renal anomalies, asphyxiation, drug poisoning ${ }^{25}$, and prematurity are associated with renal failure in newborns and significantly increase the LOS in NICU ${ }^{24}$. Unlike our study, these factors such as sepsis, congenital renal anomalies, asphyxiation and drug poisoning, were not confirmed as an effective factors in LOS in $\mathrm{Lee}^{26}$ and Altman's ${ }^{27}$ studies.

The findings of the present study suggest that blood transfusion and phototherapy are positively associated with LOS among infants. The majority of newborns develop jaundice within a few days of birth, and mostly receive phototherapy with a special light. These infants require hospitalization to receive treatment. These findings were consistent with the results of previous studies ${ }^{28,29}$. Moreover, a number of previous studies have shown that premature or low birth weight infants who are more likely to have prolonged LOS need blood transfusion several times during hospital stay ${ }^{30,31}$. These results were not achieved in Bender ${ }^{32}$ and Manktelow's ${ }^{33}$ studies. As a result, various regression models show different effectiveness in the analysis of different data sets and we need to evaluate the different parametric and semiparametric models to find the most effective $\operatorname{model}^{34,35}$.

The study had some limitations. The required data were extracted from the hospital information system, and some of the study variables may not be accurately documented. Besides, this study reviewed medical records of one single hospital and results may not be applicable to other hospitals in Bandar Abbas city.

\section{Conclusions}

The type of feeding, umbilical and central venous catheterization, mechanical ventilation, nosocomial infection, acute renal failure, blood transfusion, and antibiotic therapy were significantly associated with LOS in the NICU.

\section{References}

1. Lawn JE, Cousens SN, Darmstadt GL, Bhutta ZA, Martines J, Paul V, et al. One year after The Lancet Neonatal Survival Series - Was the call for action heard? The Lancet 2006; 367(9521):1541-7. https://doi.org/10.1016/S01406736(06)68 587-5 
2. Murray CJ, Laakso T, Shibuya K, Hill K, Lopez AD. Can we achieve Millennium Development Goal 4? New analysis of country trends and forecasts of under-5 mortality to 2015. The Lancet 2007; 370(9592):1040-54.

https://doi.org/10.1016/S01406736(07)61

478-0

3. MacDorman MF, Hoyert DL, Mathews T. Recent declines in infant mortality in the United States, 2005-2011. NCHS Data Brief 2013;120:1-8.

4. Field DJ, Dorling JS, Manktelow BN, Draper ES. Survival of extremely premature babies in a geographically defined population: prospective cohort study of 1994-9 compared with 2000-5. British Medical Journal 2008; 336(7655): 1221-3.

https://doi.org/10.1136/bmj.39555.670718 .be

PMid:18469017 PMCid:PMC2405852

5. Manktelow BN, Seaton SE, Field DJ, Draper ES. Population-based estimates of in-unit survival for very preterm infants. Pediatrics 2013:peds. 2012-189.

6. Lee HC, Bennett MV, Schulman J, Gould JB, Profit J. Estimating length of stay by patient type in the neonatal intensive care unit. American Journal of Perinatology 2016;33(08):751-7.

https://doi.org/10.1055/s-0036-1572433

PMid:26890437

7. Turner M, Winefield H, Chur-Hansen A. The emotional experiences and supports for parents with babies in a neonatal nursery. Advances in Neonatal Care 2013;13(6):438-46.

https://doi.org/10.1097/ANC.0000000000 000030

PMid:24300964

8. Kandi Kele M, Kadivar M, Zeraati H, Ahmadnezhad E, Holakoui Naini K. Length of Stay in NICU Admitted Infants and Its Effective Factors at Children's Hospital Medical Center Using Survival Analysis. Iranian Journal of Epidemiology 2014;10(1):25-32.

9. Cannoodt L, Knickman J. The effect of hospital characteristics and organizational factors on pre-and postoperative lengths of hospital stay. Health Services Research 1984;19(5):561.

\section{PMid:6500957 PMCid:PMC1068835}

10. Pepler F, Uys DW, Nel DGJAhs. Predicting mortality and length-of-stay for neonatal admissions to private hospital neonatal intensive care units: a Southern African retrospective study. African Health Sciences 2012;12(2):166-73.

https://doi.org/10.4314/ahs.v12i2.14 PMid:23056023 PMCid:PMC3462546

11. Lamberti LM, Zakarija-Grković I, Walker CLF, Theodoratou E, Nair H, Campbell H, et al. Breastfeeding for reducing the risk of pneumonia morbidity and mortality in children under two: a systematic literature review and meta-analysis. BMC Public Health 2013;13(3):S18.

https://doi.org/10.1186/1471-2458-13-S3S18

PMid:24564728 PMCid:PMC3847465

12. Chung M, Raman G, Chew P, Magula N, Trikalinos T, Lau J. Breastfeeding and maternal and infant health outcomes in developed countries. Evidence Report/Technology Assesment 2007; 153(153): 1-186.

13. Naficy AB, Abu-Elyazeed R, Holmes JL, Rao MR, Savarino SJ, Kim Y, et al. Epidemiology of rotavirus diarrhea in Egyptian children and implications for disease control. American Journal of Epidemiology 1999; 150(7):770-7.

https://doi.org/10.1093/oxfordjournals.aje. a010080

PMid:10512431

14. Herrmann K, Carroll K. An exclusively human milk diet reduces necrotizing enterocolitis. Breastfeeding Medicine 2014; 9(4):184-90.

https://doi.org/10.1089/bfm.2013.0121

PMid:24588561 PMCid:PMC4025624

15. Meinzen-Derr J, Poindexter B, Wrage L, Morrow A, Stoll B, Donovan E. Role of human milk in extremely low birth weight infants' risk of necrotizing enterocolitis or death. Journal of Perinatology 2009; 29(1):57.

https://doi.org/10.1038/jp.2008.117

PMid:18716628 PMCid:PMC2801431

16. Darvishpour A, Hashemian H, Faal E, Fasihi M. Survey of nosocomial infection and accompanied factors in neonatal intensive care unit. Journal of Guilan 
University of Medical Sciences 2010; 19(73): 37-45.

17. Joseph CJ, Lian WB, Yeo CLJPoSH. Nosocomial infections (late onset sepsis) in the neonatal intensive care unit (NICU). Proceedings of Singapore Healthcare 2012; 21(4):238-44. https://doi.org/10.1177/201010581202100 404

18. Afjeh S-A, Sabzehei M-K, Seyyed-AliReza Fahimzad FS, Shamshiri A-R, Esmaili FJIjop. Antibiotic therapy for very low birth weight newborns in NICU. Iranian Journal of Pediatrics 2016; 26(2): 2612

PMid:27307961 PMCid:PMC4904487

19. Sabzeie MK, Sabouri T, Sokri M, Basiri B. The study of pulmonary complications of neonatal mechanical ventilation in NICU. Scientific Journal of Hamadan University of Medical Sciences 2016; 22(4):269-75.

20. Hossain MM, Shirin M, Al Mamun MA, Hasan MNA, Sahidullah MJBJoCH. Predictors of mortality in ventilated neonates in intensive care unit. Bangladesh Journal of Child Health 2009; 33(3):77-82.

21. Iqbal Q, Younus MM, Ahmed A, Ahmad I, Iqbal J, Charoo BA, et al. Neonatal mechanical ventilation: Indications and outcome. Indian Journal of Critical Care Medicine 2015; 19(9):523-7.

https://doi.org/10.4103/0972-5229.164800 PMid:26430338 PMCid:PMC4578196

22. Jetton JG, Askenazi DJ. Acute kidney injury in the neonate. Clinics in Perinatology 2014;41(3):487-502. https://doi.org/10.1016/j.clp.2014.05.001 PMid:25155722

23. Askenazi DJ, Ambalavanan N, Hamilton K, Cutter G, Laney D, Kaslow R, et al. Acute kidney injury and renal replacement therapy independently predict mortality in neonatal and pediatric noncardiac patients on extracorporeal membrane oxygenation. Pediatric Critical Care Medicine 2011; 12(1):e1-e6. https://doi.org/10.1097/PCC.0b013e3181d $8 \mathrm{e} 348$

PMid:20351617

24. Koralkar R, Ambalavanan N, Levitan EB, McGwin G, Goldstein S, Askenazi D. Acute kidney injury reduces survival in very low birth weight infants. Pediatric

Research 2011; 69(4):354.

https://doi.org/10.1203/PDR.0b013e31820

b95ca

PMid:21178824

25. Azat NFA, abdalmahdi Salih A, Naoom MB. Acute renal failure in neonates. Iraqi Academic Scientific Journal 2011; 10(2): 145-8.

26. Lee HC, Bennett MV, Schulman J, Gould JB. Accounting for variation in length of NICU stay for extremely low birth weight infants. Journal of Perinatology 2013; 33:872.

https://doi.org/10.1038/jp.2013.92

PMid:23949836 PMCid:PMC3815522

27. Altman M, Vanpée M, Cnattingius S, Norman M. Moderately preterm infants and determinants of length of hospital stay. Archives of Disease in Childhood - Fetal and Neonatal Edition 2009; 94(6):F414-F8 https://doi.org/10.1136/adc.2008.153668 PMid:19465411

28. Neghabadi FP, Nourian M, Farahani AS, Pourhoseingholi MA, Shoorideh FAJIJCCN. Auditing phototherapy-related nursing care in neonatal general and intensive care units. Iranian Journal of Critical Care Nursing 2015; 8(3):167-72.

29. Hashim ME, Said RN, Abdallah EAA, Elghafar HFAJIJoP, Medicine A. Evaluation of phototherapy with reflectors: A randomized controlled trial. International Journal of Pediatrics and Adolescent Medicine 2015; 2:117-22. https://doi.org/10.1016/j.ijpam.2015.09.00 3

30. Chirico GJIJoCTM. Red blood cell transfusion in preterm neonates: current perspectives. International Journal of Clinical Transfusion Medicine 2014; 2:218.

31. Borna H, Rafati S, Tehrani FHE, Gadimii SJTUMJ. The prevalence and assessment of blood transfusions in newborns. Tehran University Medical Journal 2017; 75(3):200-7.

32. Bender GJ, Koestler D, Ombao H, McCourt M, Alskinis B, Rubin LP, et al. Neonatal intensive care unit: predictive models for length of stay. Journal of Perinatology 2012; 33:147. 
https://doi.org/10.1038/jp.2012.62

PMid:22678140 PMCid:PMC4073289

33. Manktelow B, Draper ES, Field C, Field D. Estimates of length of neonatal stay for very premature babies in the UK. Archives of Disease in Childhood - Fetal and Neonatal Edition 2010; 95(4):F288-F92. https://doi.org/10.1136/adc.2009.168633 PMid:20530099

34. Kargarian Marvasti S, Abolghasemi J, Heydari I, Rimaz S. Effective Factors in the time of development of neuropathy in Type II Diabetic patients. Iranian Journal of Epidemiology 2017;13(2):80-9.
35. Kargarian-Marvasti S, Rimaz S, Abolghasemi J, Heydari I. Comparing of Cox model and parametric models in analysis of effective factors on event time of neuropathy in patients with type 2 diabetes. Journal of Research in Medical Sciences 2017; 22:115.

https://doi.org/10.4103/jrms.JRMS_6_17 PMid:29184573 PMCid:PMC5680655 